\title{
ACKNOWLEDGMENT TO REVIEWERS
}

\section{Al-Ta'lim Journal acknowledges and appreciates to the following scholars for their dedication as reviewers for Volume 22 Number 12015 :}

1. Dr. Zifirdaus Adnan, School of Arts, University of New England, Amidale, NSW, Australia.

2. Prof. Dr. Oktavianus, Faculty of Arts and Literature University of Andalas Padang, Indonesia.

3. Prof. H. Syaiful Anwar, IAIN Raden Intan Lampung, Indonesia.

4. Dr. Bistari, Department of Math, Tanjung Pura University, West Kalimantan, Indonesia.

5. Ismail Suardi Wekke, Ph.D., STAIN Sorong, Indonesia.

6. Prof. Syamsul Nizar, Department of Islamic Education, Islamic University of Sutan Syarif Kasim Riau, Indonesia.

7. Prof. Dr. Asnawir, Department of Islamic Education, State Institute for Islamic Studies IB Padang, Indonesia.

8. Prof. Dr. Syafruddin Nurdin, Department of Islamic Education, State Institute for Islamic Studies IB Padang, Indonesia.

9. Prof. Dr. Ramayulis, Department of Islamic Education, State Institute for Islamic Studies IB Padang, Indonesia.

10. Prof. Dr. Masnal Zajuli, Department of Arabic, State Institute for Islamic Studies IB Padang, Indonesia.

11. Prof. Dr. H. Armen Mukhtar, Department of Arabic, State Institute for Islamic Studies IB Padang, Indonesia.

12. Prof. Zulmuqim, MA, Department of Islamic Education Management, State Institute for Islamic Studies IB Padang, Indonesia.

13. Dr. Teuku Zulfikar, Department of English, State Institute for Islamic Studies IB Padang, Indonesia.

14. Dr. Hafni Bustami, Department of Arabic, State Institute for Islamic Studies IB Padang, Indonesia. 